\title{
Tekmeria
}

Vol 11 (2012)

TOMEA EAAHNIKHE KAI PEMAIKHE APXAOTHTA

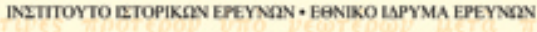

SECTION OF GREEK AND ROMAN ANTQUITY
INSTITUTE OF HISTORICAL RESENRCH + NATONAL. HEUENIC RESEARCH FOUNDNTION

(2012)

$$
\text { ATHENS } 2013
$$

DITUSION DE BOCCARD - 11 , KUE DE MEDACIS, 7906 RMRIS

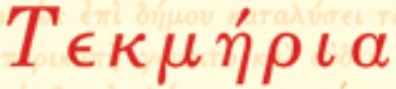

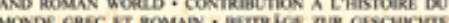

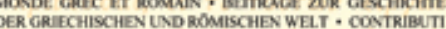
PLELA STORLA DEL MONDO GRFCOE ROMASO

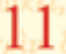 \\ 11}

\section{A Note on the Athenian Hiereus of Drusus Hypatos}

\section{Francesco Camia}

doi: $\underline{10.12681 / \text { tekmeria.283 }}$

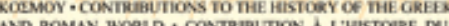

\section{To cite this article:}

Camia, F. (2013). A Note on the Athenian Hiereus of Drusus Hypatos. Tekmeria, 11, 37-50.

https://doi.org/10.12681/tekmeria.283 


\section{FRANCESCO CAMIA}

\section{A Note on the Athenian Hiereus of Drusus Hypatos*}

\section{A cult for Drusus the Elder in Athens}

In 9 BC Drusus the Elder, son of the future spouse of Augustus, Livia Drusilla, passed away near Mogontiacum (modern Mainz) during a military campaign against the German tribes. The Senate awarded him solemn funerary honours. ${ }^{1}$ Probably in the same year, or a little later, a "priest of the consul Drusus" (ispev̀s

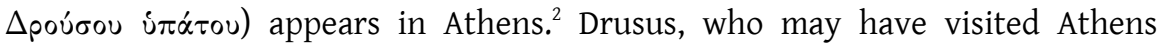

\footnotetext{
${ }^{*}$ This paper is part of a wider research project of the author on the priests of Roman Athens. I thank S. Privitera who read through the article and made precious suggestions and M. Metcalfe who edited the English text. The following bibliographical abbreviations are used:

- Byrne, Roman Citizens = S.G. Byrne, Roman Citizens of Athens (Studia Hellenistica 40, Leuven - Dudley, Mass. 2003)

- Camia, Theoi Sebastoi = F. Camia, Theoi Sebastoi. Il culto degli imperatori romani in Grecia (provincia Achaia) nel secondo secolo d.C. (Meletemata 65, Athens 2011)

- Kantirea, Dieux Augustes = Maria Kantirea, Les dieux et les dieux Augustes. Le culte impérial en Grèce sous les Julio-claudiens et les Flaviens. Études épigraphiques et archéologiques (Meletemata 50, Athens 2007)

- Schmalz, Athens = G.C.R. Schmalz, Augustan and Julio-Claudian Athens. A New Epigraphy and Prosopography (Leiden - Boston 2009).

1. Cass. Dio 55.2; F. Hurlet, Les collègues du prince sous Auguste et Tibère: de la légalité républicaine à la légitimité dynastique (CEFR 227, Paris 1997) 94-95. The death of Drusus, who was well loved by the people, provoked great grief among the Romans; cf. H. Schoonhoven (ed.), The Pseudo-Ovidian Ad Liviam de Morte Drusi (Consolatio ad Liviam, Epicedium Drusi): A Critical Text with Introduction and Commentary (Groningen 1992) 181-198. In AD 6 Drusus' sons Germanicus and Claudius organized a gladiatorial spectacle in Rome in honour of their father (Cass. Dio 55.27.3), while Claudius, once he had become emperor, instituted Circensian games in honour of their parents to be celebrated every year on Drusus' birthday (Suet. Claud. 11.2; Cass. Dio 60.5.1). Herod of Judea is said to have named a fortress tower in Caesarea after Drusus (Joseph AJ 15.336; BJ 1.412). On Drusus the Elder cf. PIR ${ }^{2}$ C 857; RE III 2 (1899) 2703-2719, s.v. Claudius 139 (A. Stein); see also D. Kienast, Römische Kaisertabelle (second revised edition, Darmstadt 1996; first edition 1990) 68-69 (with previous bibliography).

2. Earliest epigraphic reference: IG II $^{2} 1722$, 1l. 1-3 (archon list; 9/8 BC or a little later); cf. P. Graindor, Chronologie des archontes athéniens sous l'empire (Brussels 1922) 50, no. 16. On the priesthood of the consul Drusus cf. P. Graindor, Athènes sous Auguste (Cairo 1927) 157;
} 
before $18 \mathrm{BC}$, was honoured (on the same occasion?) as a benefactor by the Athenians with a statue on the Acropolis. ${ }^{3}$ The institution of a cult of Drusus, however, must have followed his death. This can be inferred by the very title of this priesthood's holders, as the name of Drusus is accompanied by the mention

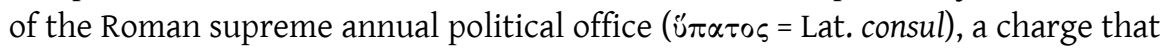
Drusus assumed in $9 \mathrm{BC}$ and was still holding when he died. This fact can also help to explain another peculiarity of this priesthood, i.e. its association - likely since its creation - with the Athenian supreme annual political office of eponymous archon. It seems that following the creation of the cult of Drusus, Athenian archons assumed this priesthood at the same time; indeed, as has been noted, no preserved archon list dated after $9 / 8 \mathrm{BC}$ omits to mention the priesthood of the consul Drusus, next to the office of eponymous archon. ${ }^{4}$ Simone Follet has rightly suggested that the first holder of this priesthood was perhaps an eponymous archon, and that from that moment onwards this religious function would have remained strictly associated with the office of archon. ${ }^{5}$ The choice to assign the new priesthood of Drusus to the eponymous Athenian magistrate might have been also determined by the archon's religious duties in connection

id., Athènes de Tibère à Trajan (Cairo 1931) 116; id., Athènes sous Hadrien (Cairo 1934) 171; D.J. Geagan, The Athenian Constitution after Sulla (Hesperia Suppl. 12, Princeton 1967) 8 (and nn. 45-46); Kantirea, Dieux Augustes 62-63 and 222-224, nos. 18-32; F. Lozano, La religiòn del Poder. El culto imperial en Atenas en época de Augusto y los emperadores Julio-Claudios (BAR 1087, Oxford 2002) 30.

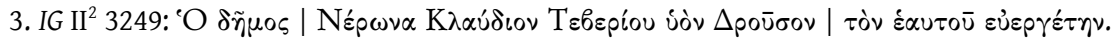
Cf. Graindor, Auguste (see n. 2) 50 and 157-158; Kantirea, Dieux Augustes 62. See also IG IV 595-596 (Epidaurus): two honorary inscriptions for Drusus; IvO 369 (Olympia): honorary inscription for Drusus and his brother, the future emperor Tiberius, set up by the Elean

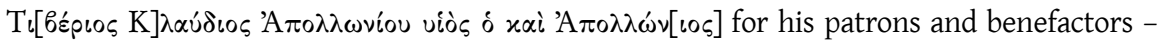
six honorary monuments for Tiberius dating before his adoption by Augustus are known from Athens (IG II ${ }^{2}$ 3243-3248). Cf. Sophia Zoumbaki, "Tiberius und die Städte des griechischen Ostens: Ostpolitik und hellenisches Kulturleben eines künftigen Kaisers", in Y. Perrin (ed.), Neronia VII. Rome, l'Italie et la Grèce. Hellénisme et philhellénisme au premier siècle après J.-C. Actes du VII Colloque international de la SIEN, Athènes, 21-23 octobre 2004 (Brussels 2007) 158-169 (esp. 165-166).

4. S. Dow, "The Lists of Athenian Archontes", Hesperia 3 (1934) 149: "no list (scil. archon list) dated after 9/8 certainly lacks it (scil. Drusus' priesthood)"; ibid. 186: "the Archon was always and not occasionally in these documents (scil. archon lists) recorded as Priest of Drusus after 9/8 B.C."; see also Geagan, Athenian Constitution (see n. 2) 8.

5. Cf. Kantirea, Dieux Augustes 63. 
with the imperial cult. ${ }^{6}$ In any case, the fact that it was the eponymous archon who assumed the priesthood of Drusus made it an annual office, unlike other imperial priesthoods, both in Athens and in other Greek cities, which instead were held for life. ${ }^{7}$ Yet the most striking peculiarity of the Athenian priesthood of Drusus is its exceptional duration, as it continues to be attested epigraphically - albeit not regularly, as will be made clear shortly - from the end of the 1st cent. $\mathrm{BC}$ until the beginnings of the 2nd cent. AD. ${ }^{8}$ This is in contrast with what is known of other cults of specific members of the imperial family, which usually

6. As attested by a decree in honour of Julia Domna (IG $\mathrm{II}^{2}$ 1076), at the latest by the beginning of the 3rd cent. AD the eponymous archon took part, both individually as a magistrate and collegially as a member of the board of archons, in the celebrations of the imperial cult; cf. Geagan, Athenian Constitution (see n. 2) 9. Despite the late date of this epigraphic document, it is reasonable to assume that this holds true already from the earliest phases of the Athenian imperial cult.

7. Cf. IG II 3595 (Athens; ca. AD 120): Ti. Claudius Atticus, archiereus of the Sebastoi dì̀ biov; on the Athenian archiereis of the Sebastoi see most recently Camia, Theoi Sebastoi 137144 (esp. 138-140 for Atticus). IG V 1, 971 (Asopos; Hadrian): C. Iulius Eurycles Herculanus, archiereus of the Sebastoi $\delta i \dot{\alpha}$ biou at Sparta - NB: in the latter city likely around the middle of the 2nd cent. AD the priesthood of the emperors changed from being a lifelong charge to an annual office; see F. Camia and Maria Kantirea, "The Imperial Cult in the Peloponnese", in A.D. Rizakis and Claudia E. Lepenioti (eds.), Roman Peloponnese III. Society, Economy and Culture under the Roman Empire: Continuity and Innovation (Meletemata 63, Athens 2010) 389-395 (esp. 393, n. 145). IvO 447 (Olympia; end of 1st-beginning of 2nd cent. AD): Ti. Claudius (Dionysius) Crispianus, archiereus of the Sebastoi dı̀ biov at Messene; cf. Camia and Kantirea, "Imperial Cult" (see supra) 396, with n. 169. IG V 2, 515B, 11. 29-30 (Lykosoura; 1st cent. AD): Xenarchos archiereus of the Sebastoi Sı⿱亠乂 biou at Megalopolis; cf. Camia and Kantirea, "Imperial Cult" (see supra) 397. SEG 45 (1995) 257 (Argos; late 1st cent.

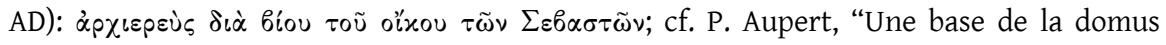
augusta domitienne à Argos ?", Pallas 40 (1994) 69-77 - for an imperial hiereus for life (of

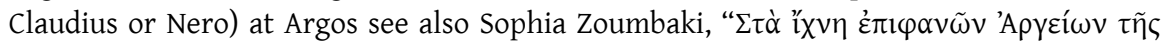

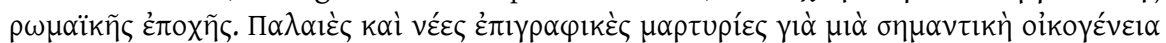

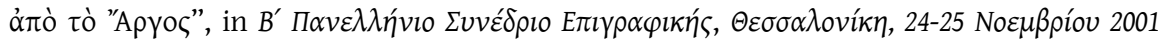
(Thessalonike 2008) 115-134. IG VII 111 (Megara; 2nd-3rd cent. AD): Polymnia, archiereia of

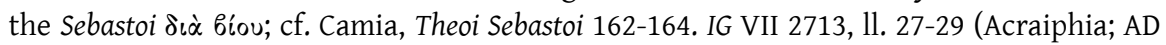
66/7): Epameinondas, archiereus of the Sebastoi Sı̀े biov; cf. Kantirea, Dieux Augustes 178180, 232, no. 68 .

8. See infra. 
had a limited life, not to mention the fact that in the Greek world emperor worship was focused on the living emperor. ${ }^{9}$

In fact, Drusus' cult represents an anomaly in the evolution of the Athenian imperial cult. In the years following the institution of the priesthood of Drusus the Elder, and until the middle of the 1st cent. AD, several cults for specific individuals of the imperial family coexisted in Athens with that for the reigning emperor, each with its own priest, ${ }^{10}$ it is worth noting that a cult with a specific priestess is also attested for Drusus' spouse Antonia Minor..$^{11}$ In this respect, the presence of a priesthood of Drusus is not strange at all, independent of the particular occasion (probably Drusus' death) which led to the decision to create this cult. Around the middle of the first century, however, a reform took place which resulted in a more centralised organisation of the Athenian imperial cult: from that moment onwards this cult was addressed collectively to the Sebastoi even though the reigning emperor continued, quite obviously, to maintain a prominent position - and the various priests of specific imperial figures were replaced by a high priest (archiereus) of the Sebastoi, who served for life. ${ }^{12}$ As a result, the cult of Drusus became in a way a legacy of the past, a deviation from the (new) norm of the organisational structure of the cult of the emperors. ${ }^{13}$ It is my contention that the reason for its exceptional duration is to be found in its

9. Cf. S.R.F. Price, Rituals and Power. The Roman Imperial Cult in Asia Minor (Cambridge 1984) 61: “... cults of individual emperors did not long endure the death of that emperor".

10. Cf. IG II 3173 (hiereus of the goddess Roma and Augustus); IG II 5161 (seat of the theatre of Dionysos for the hiereus or hiereia of Livia); IG II 5096 (seat of the theatre of Dionysos for the hiereia of Hestia on the Acropolis, Livia and Iulia); IG $\mathrm{II}^{2} 3266$, with Kantirea, Dieux Augustes 80 (hiereus of Valeria Messalina, Claudius' third wife); I.Eleusis 354 (hiereus of Iulia Agrippina, Nero's mother). See also IG II $^{2} 3547$ (hiereus of the Roman senate, the Demos and the Charites); IG II ${ }^{2} 4720$ (hiereus of the Iustitia Augusta).

11. IG II $^{2} 5095$ (Tiberian): seat of the theatre of Dionysos reserved for the priestess of Antonia Minor. An archiereus of Antonia Minor is also attested (IG II ${ }^{2} 3535$, 11. 10-11; middle of the 1st cent. AD).

12. Cf. A.J.S. Spawforth, "The Early Reception of the Imperial Cult in Athens", in M.C. Hoff and Susan I. Rotroff (eds.), The Romanization of Athens. Proceedings of an International Conference Held at Lincoln, Nebraska, April 1996 (Oxford 1997) 188-191; Kantirea, Dieux Augustes 175-178; Camia, Theoi Sebastoi 207.

13. It is worth noting here a fragmentary dedication in Latin to Drusus the Elder from the Roman colony of Philippi, dated during the reign of Claudius (Drusus' son), that was found inside the cella of the so-called Eastern temple of the forum, possibly to be identified with a temple of the imperial cult (I.Philippi $\left.{ }^{2} 232 a\right)$. 
particular association with the eponymous archons, who assumed annually the priesthood of Drusus. With regard to this, it can be noted that the absence of any type of evidence for this cult except for the epigraphic references of a priesthood could lead one to doubt its very existence and to suppose that at least after the middle of the first century "hiereus of Drusus hypatos" had been turned into a mere title held by the archons without any direct correspondence with a real cult. This, however, is an argumentum ex silentio which cannot be proved; in fact, one has to conclude that as long as a priesthood of Drusus is attested in the epigraphic evidence there must have been also some form of cult practice.

\section{The epigraphic evidence for the hiereus of Drusus hypatos}

As has long been noted, the function of hiereus of the consul Drusus is mentioned with regularity in the archon lists: all preserved laterculi archontum dated after 9/8 BC mention the priesthood of the consul Drusus. ${ }^{14}$ In other documents this title is not mentioned with the same regularity, and this is likely due to the very close relationship that existed between the political office of eponymous archon and the religious function of priest of Drusus: the latter title was evidently omitted in many cases (particularly when occurring in the formula of eponymity) as it was implicit that the archon used also to assume at the same time the priesthood of Drusus.

There are overall about twenty epigraphic references to the priest of Drusus, which range chronologically between the end of the 1st cent. $\mathrm{BC}$ and the beginning of the 2nd cent. AD (see Table 1). About one quarter (six) occur in archon lists, and another quarter in honorary inscriptions (two referring to the same individual). The title also occurs in four ephebic catalogues, three decrees, two votive dedications, one ephebic dedicatory monument, and finally on a statue base with an artist's signature. It is worth noting that apart from the archon lists, the only category of documents in which the priest of Drusus is not mentioned in the formula of eponymity is that of honorary inscriptions: in all of the six preserved honorary texts the title occurs in accusative case among the offices held by the honoree. In all the other cases the title is instead mentioned in the formula of eponymity ( $\dot{\varepsilon} \pi \dot{i}+$ the genitive case), as in this type of documents the archon is usually mentioned in the eponymic function. More interestingly, there are as yet no other honorary inscriptions that mention only the office of eponymous archon for any of the holders of the priesthood of Drusus attested by these six honorary

14. See n. 4. 
inscriptions. In this respect, it is to be noted more generally that, as far as I know, none of the (admittedly few) honorary inscriptions dated between the end of the 1 st cent. $\mathrm{BC}$ and the beginning of the 2nd cent. $\mathrm{AD}$ and mentioning the office of eponymous archon certainly lacks the function of hiereus of Drusus hypatos. This means that after the institution of the priesthood of Drusus the tendency in honorary inscriptions was to indicate, next to the office of eponymous archon, also the title of hiereus of Drusus hypatos. In other words, it seems that the latter was regularly mentioned not only in the archon lists but also in the honorary monuments for holders of the Athenian eponymous magistracy, with the exception of those cases when the office of eponymous archon was indicated with the

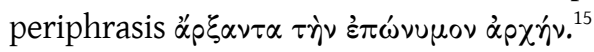

At a certain moment the title of "hiereus of Drusus hypatos" disappears from the epigraphic record. It is usually held that Drusus' priesthood as well as the corresponding cult ceased to exist sometime during the reign of Hadrian. This thesis, formulated at the end of the 19th century by Dittenberger, ${ }^{16}$ has become the communis opinio repeated by the (few) scholars who have touched on mainly in passing and a latere of other subjects such as that of the Athenian eponymous archonship - the priesthood of Drusus, albeit without discussing in any detail the chronological aspect of the matter nor trying to contextualize historically the disappearance of this cult. ${ }^{17}$ This opinion is essentially based on IG II 3572 and 3589, two honorary inscriptions for L. Vibullius Hipparchus and T. Flavius Alcibiades respectively, traditionally dated to the first years of the reign of Hadrian (AD 118/9 and 122/3), that represent the latest references to the priesthood of Drusus: the latter would disappear in the following years. It is however to be noted that these two honorary inscriptions are to be dated earlier, as in all probability Hipparchus and Alcibiades were eponymous archons by the first decade of the second century (AD 100/1 and 104/5 respectively). ${ }^{18}$

15. Cf. IG II ${ }^{2} 3546-3547$ (1st cent. AD), where the reference to the role of priest of the consul Drusus is missing.

16. Commentary to IG III 1005: “... Hadriani imperio, quo tempore id sacerdotium [scil. Drusus' priesthood] abolitum esse videtur”.

17. See most recently D.J. Geagan, Inscriptions: The Dedicatory Monuments (The Athenian Agora XVIII, Princeton 2011) 77: "Archonships combined with the priesthood of the consul Drusus occur from the death of Drusus as consul in 9 B.C. until Hadrian's reign".

18. Byrne, Roman Citizens 508; see also ibid. 478, no. 2 and 256, no. 131. Cf. Simone Follet, Athènes au II et au III siècle. Études chronologiques et prosopographiques (Paris 1976) 507: Vibullius Hipparchus $=$ AD 97/8-102/3; Flavius Alcibiades $=$ AD 101/2-106/7; E. 
The latest epigraphic reference of the priesthood of Drusus (IG $\mathrm{II}^{2}$ 3589) therefore dates to before the end of the reign of Trajan, and as a consequence the terminus post quem for the disappearance of the hiereus (and the cult) of Drusus is to be raised to ca. AD 105. What happened afterwards? Due to the irregular way the title of hiereus of the consul Drusus is mentioned in the epigraphic evidence it is difficult to answer this question, yet some considerations can be made in order to try to better contextualize the end of the cult of Drusus.

\section{The end of the priesthood of Drusus}

As I have noted above, except for the archon lists, honorary inscriptions for eponymous archons are the only category of texts that seem to mention regularly the function of priest of Drusus next to the archonship. An honorary inscription dated after IG $\mathrm{II}^{2} 3589$ (T. Flavius Alcibiades, eponymous archon in AD 104/5) and not mentioning the function of hiereus of Drusus next to the office of archon could therefore be used as an indirect proof of the disappearance of Drusus' priesthood, thus providing a terminus ante quem for the end of the corresponding cult. As far as I know, the first text of such a type after IG $\mathrm{II}^{2} 3589$ is an honorary inscription from Epidaurus' Asklepieion for Q. Alleius Epictetus, who was eponymous archon in Athens likely around AD 130-140:19 in this text there is no mention of the priesthood of Drusus, which evidently was no longer in existence at the time Epictetus held the archonship. From what precedes one can argue that the priesthood of Drusus as well as the corresponding cult must have disappeared sometime between ca. AD 105 and $1400^{20}$

Kapetanopoulos [http://www.history.ccsu.edu/elias/eliasarchontes.htm]: 99/100 and 107/8 AD respectively.

19. IG IV ${ }^{2}$ 691; W. Peek, Inschriften aus dem Asklepieion von Epidaurus (Berlin 1969) no. 302; on the individual cf. Byrne, Roman Citizens 50, no. 3.

20. For the archons between T. Flavius Alcibiades and Q. Alleius Epictetus (see list in Byrne, Roman Citizens 508) all of the references we have to their archonships are in the formula of eponymity; as in these cases the title of hiereus of Drusus was often omitted, these epigraphic references cannot be used to draw any conclusion regarding the existence of the priesthood. To my knowledge the only exception is represented by an Eleusinian honorary inscription (I.Eleusis 455) for Vipsanius Aiolion, eponymous archon likely around AD 110-115 (Byrne, Roman Citizens 490-491, no. 9, who dates the inscription to ca. AD 120; contra Clinton [I.Eleusis 455] dates the text to ca. AD 140-150 and Aiolion's archonship to the end of the 1st cent. AD); yet in this text the archonship is mentioned

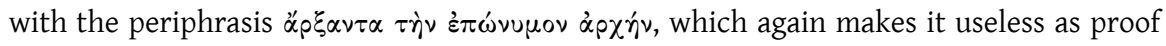
of the disappearance of the priest of Drusus at the time Aiolion was archon (cf. the 
With few yet illuminating words in the commentary to one of the preserved Athenian archon lists, Dittenberger had stated that the proliferation of honours for the emperor Hadrian following his first official visit to the city (AD 124/5) would have finally provoked the end of Drusus' priesthood: "A primo Hadriani Caesaris Athenas adventu, cum tot tantique novi honores in hunc imperatorem cumularentur, ex priorum imperatorum honoribus divinis nonnulli, et inter eos illud Drusi sacerdotium, in desuetudinem venisse videntur". ${ }^{21}$ Indeed, after his ascent to the throne in AD 117, Hadrian deployed his great love for the city of Athens, which he visited in an official capacity three times (AD 124/5, 128/9, 131/2) and embellished with various buildings, making it the administrative and religious center of the new league of the Panhellenion. ${ }^{22}$ Equally 'warm', at least at the official level, was the Athenians' reply to the emperor's benevolent attitude towards their city, which is documented by both human and divine honours, along which innumerable statues and altars ${ }^{23}$ not to mention the new tribe Hadrianis that was created in his honour. ${ }^{24}$ Hadrian was worshipped in Athens as a real god and impressed a decisive mark on the Athenian imperial cult. In fact, it can be said that Hadrian's reign came to 'unhinge', at least temporarily, a system that left little or no space for individual imperial figures: in a cultic context that since the midfirst century had been dominated by the high priest of the Sebastoi, a specific priest of the reigning emperor reappeared (hiereus of Hadrian Eleuthereus ${ }^{25}$ ) and a new

honorary inscriptions of the 1st cent. AD IG II 3546 and 3547, in which the archonship is mentioned with the above periphrasis and no mention is made of the office of priest of Drusus, which certainly still existed at that time).

21. IG III 1009 [ $=$ IG II ${ }^{2}$ 1724].

22. A.R. Birley, Hadrian. The Restless Emperor (London - New York 1997) 182-184, 218-220, 262-266. For the Panhellenion see Graindor, Hadrien (see n. 2) 102-111; J.H. Oliver, Marcus Aurelius. Aspects of Civic and Cultural Policy in the East (Hesperia Suppl. 13, Princeton 1970) 90138; A.J.S. Spawforth and Susan Walker, "The World of the Panhellenion I. Athens and Eleusis”, JRS 75 (1985) 78-104; C.P. Jones, “The Panhellenion”, Chiron 26 (1996) 29-56; A.J.S. Spawforth, "The Panhellenion Again", Chiron 29 (1999) 339-352; Mary T. Boatwright, Hadrian and the Cities of the Roman Empire (Princeton 2000) 147-150.

23. Cf. Camia, Theoi Sebastoi 252-257.

24. Paus. 1.5.5; cf. T.L. Shear Jr., "The Monument of the Eponymous Heroes in the Athenian Agora", Hesperia 39 (1970) 202-203.

25. IG II $^{2} 5035$ (the epithet was added later); cf. M. Maas, Die Prohedrie des Dionysostheaters in Athen (Munich 1972) 116-117; L. Threatte, The Grammar of Attic Inscriptions (Berlin - New York 1980) 299, no. 95. In the context of the league of the Panhellenion a hiereus of Hadrian Panhellenios also existed (cf. Camia, Theoi Sebastoi 44-46). 
imperial festival named after Hadrian himself was instituted (Hadrianeia) ${ }^{26}$ In this context the presence of the cult of Drusus would represent a strident anomaly, especially after Hadrian's third and final visit in AD 131/2, when the definitive inauguration of the Olympieion and the foundation of the Panhellenion were celebrated with a solemn ceremony. ${ }^{27}$ As Dittenberger suggested, it is thus reasonable to assume that Drusus' cult came to an end during Hadrian's reign. However, one could hypothetically suggest a slightly different scenario. There is a specific episode that took place prior to Hadrian's accession to the power that may have determined the end of this priesthood, or at least have represented the first step towards its dismissal. I am referring to Hadrian's unofficial visit to Athens in AD 111/2. The future emperor, at that time a privatus, was already in an advanced stage of his senatorial career, having held the consulship in $\mathrm{AD}$ 108. In Athens, Hadrian was offered the eponymous archonship, and the three highest Athenian civic institutions (council of the Areopagus, council of six hundreds, popular assembly) dedicated a statue of him in the theatre of Dionysos, the base of which bears a Latin inscription with his cursus honorum, followed by the mention in Greek of the office of eponymous archon. ${ }^{28}$ In his quality as archon, Hadrian was also supposed to hold the priesthood of Drusus, which is not mentioned in the inscription. One can wonder whether the Athenian authorities found that the assumption of the priesthood of a past consul by such an illustrious Roman personality - furthermore, a former consul himself - could have somehow been unfitting to his prestige and the honour they were offering him through the archonship. ${ }^{29}$ Therefore, for reasons of convenience in that year the office of hiereus of Drusus hypatos may simply have not been held, and this event could have brought about the end of this priesthood, either immediately or gradually over the following years.

In conclusion, it is my contention that the end of the priesthood (and the cult) of Drusus is to be put in relationship with the figure of Hadrian, but that at least the first act of its disappearance may have taken place before the first official visit of the philhellene emperor to Athens, insofar as the latter's visit as a

26. See e.g. F.Delphes III 1, 547, l. 14; cf. Follet, Athènes (see n. 18) 348-349. On Hadrian's cult in Athens cf. most recently Camia, Theoi Sebastoi 36-61.

27. For the date see IG IV 384 with Oliver, Marcus Aurelius (see n. 22) 119-120, no. 38 and 132-133.

28. IG $\mathrm{II}^{2} 3286$.

29. Before Hadrian, the emperor Domitian had already assumed the office of eponymous archon (see IG $\mathrm{II}^{2}$ 1996), but he had held it in absentia. 
privatus in AD 111/2 may have provided the Athenians with the occasion to get rid of a cult which had already by then basically become a relic of the past.

Table 1. The Athenian hiereis of Drusus hypatos

\begin{tabular}{|c|c|c|c|c|}
\hline Chronology & Name of priest & $\begin{array}{c}\text { Epigraphic } \\
\text { reference to the } \\
\text { office of hiereus of } \\
\text { Drusus hypatos }\end{array}$ & $\begin{array}{c}\text { Type of } \\
\text { inscription }\end{array}$ & $\begin{array}{c}\text { Further } \\
\text { observations, other } \\
\text { epigraphic } \\
\text { references and } \\
\text { bibliography }\end{array}$ \\
\hline $\begin{array}{l}\text { 9/8 BC (or a } \\
\text { little later) }\end{array}$ & $\begin{array}{l}\text { Xenon son of } \\
\text { Menneas }\end{array}$ & IG II 1722 & Archon list & \\
\hline (?) Post 9/8 BC & $\begin{array}{l}\text { Demokrates } \\
\text { son of } \\
\text { Demokrates }\end{array}$ & IG II $^{2} 1723$ & Archon list & $\begin{array}{l}\text { The title of hiereus } \\
\text { is integrated. }\end{array}$ \\
\hline Post $9 / 8 \mathrm{BC}$ & Pam[---] & IG II $^{2} 1725$ & Archon list & \\
\hline Post 9/8 BC & -------- & $I G I I^{2} 1726$ & Archon list & \\
\hline Post 9/8 BC & $\begin{array}{l}\text { Polycharmos } \\
\text { son of } \\
\text { Polykritos }\end{array}$ & IG II 3120 & $\begin{array}{l}\text { Dedication } \\
\text { (formula of } \\
\text { eponymity) }\end{array}$ & \\
\hline Post 9/8 BC & Demochares & $I G$ II $^{2} 3176$ & $\begin{array}{l}\text { Dedication } \\
\text { (formula of } \\
\text { eponymity) }\end{array}$ & \\
\hline (?) Post 9/8 BC & - - - - - - - & SEG 38 (1988) 186 & $\begin{array}{l}\text { Artist's } \\
\text { signature } \\
\text { (formula of } \\
\text { eponymity) }\end{array}$ & $\begin{array}{l}\text { The title of hiereus } \\
\text { is integrated. }\end{array}$ \\
\hline $\begin{array}{l}\text { Augustan } \\
\text { (Agora XVIII, } \\
\text { p. 77: “1st } \\
\text { cent. BC or } \\
\text { AD") }\end{array}$ & - - - - - - - & Agora XVIII C 137 & $\begin{array}{l}\text { Ephebic } \\
\text { dedication } \\
\text { (formula of } \\
\text { eponymity) }\end{array}$ & $\begin{array}{l}\text { The title of hiereus } \\
\text { is integrated but is } \\
\text { almost certain. }\end{array}$ \\
\hline $\begin{array}{l}\text { Early 1st cent. } \\
\text { AD (?) }\end{array}$ & Anaxagoras & $I G$ II $^{2} 1724$ & Archon list & $\begin{array}{l}\text { Cf. Schmalz, Athens } \\
29, \text { no. } 19 \text {. }\end{array}$ \\
\hline
\end{tabular}

30. Cf. Kantirea, Dieux Augustes 222-224, nos. 18-32. 


\begin{tabular}{|c|c|c|c|c|}
\hline Chronology & Name of priest & $\begin{array}{l}\text { Epigraphic } \\
\text { reference to the } \\
\text { office of hiereus of } \\
\text { Drusus hypatos }\end{array}$ & $\begin{array}{c}\text { Type of } \\
\text { inscription }\end{array}$ & $\begin{array}{c}\text { Further } \\
\text { observations, other } \\
\text { epigraphic } \\
\text { references and } \\
\text { bibliography }\end{array}$ \\
\hline $\begin{array}{l}\text { Augustan/ } \\
\text { Tiberian }\end{array}$ & $\begin{array}{l}\text { [Polycharmos] } \\
\text { son of Eukles }\end{array}$ & IG II $^{2} 1730$ & Archon list & $\begin{array}{l}\text { Cf. Schmalz, Athens } \\
29, \text { no. } 20 .\end{array}$ \\
\hline $\begin{array}{l}\text { First half 1st } \\
\text { cent. AD }\end{array}$ & $\begin{array}{l}\text { C. Iulius Laco } \\
\text { (Spartan) }\end{array}$ & IG II $^{2} 1069$ & $\begin{array}{l}\text { Decree } \\
\text { (formula of } \\
\text { eponymity) }\end{array}$ & $\begin{array}{l}\text { On the chronology } \\
\text { of } I G \mathrm{II}^{2} 1069 \text { see } \\
\text { most recently } \\
\text { Schmalz, Athens 16- } \\
\text { 17, no. } 7 \text { (cf. also } \\
\text { Camia, Theoi } \\
\text { Sebastoi } 105, \text { n. 413). }\end{array}$ \\
\hline $\begin{array}{l}\text { AD 39/40- } \\
40 / 1\end{array}$ & Sekoundos & $\begin{array}{l}I_{G} I^{2} \text { 82-84, 1l. 7, } \\
21\end{array}$ & $\begin{array}{l}\text { Decree } \\
\text { (formula of } \\
\text { eponymity) }\end{array}$ & $\begin{array}{l}\text { Likely to be } \\
\text { identified with C. } \\
\text { Carrinas Secundus, } \\
\text { a noted professor of } \\
\text { rhetoric at Rome } \\
\text { who was exiled by } \\
\text { Caligula in AD } 38 \\
\text { and moved to } \\
\text { Athens, where he } \\
\text { remained until his } \\
\text { death (PIR }{ }^{2} \text { C 449). } \\
\text { Cf. Schmalz, Athens } \\
\text { 63-64, no. 78; 202- } \\
\text { 203, no. 261. }\end{array}$ \\
\hline AD 41-54 & Mithridates & IG II $^{2} 1968$ & $\begin{array}{l}\text { Ephebic } \\
\text { catalogue } \\
\text { (formula of } \\
\text { eponymity) }\end{array}$ & \\
\hline $\mathrm{AD} 53 / 4-66 / 7$ & Diokles & IG II 1989 & $\begin{array}{l}\text { Ephebic } \\
\text { catalogue } \\
\text { (formula of } \\
\text { eponymity) }\end{array}$ & \\
\hline $\begin{array}{l}\text { AD 60/1 } \\
\text { (cf. Schmalz, } \\
\text { Athens 203, } \\
\text { no. 261) }\end{array}$ & Thrasyllos & IG II $^{2} 1990$ & $\begin{array}{l}\text { Ephebic } \\
\text { catalogue } \\
\text { (formula of } \\
\text { eponymity) }\end{array}$ & \\
\hline
\end{tabular}


FRANCESCo CAMIA

\begin{tabular}{|c|c|c|c|c|}
\hline Chronology & Name of priest & $\begin{array}{l}\text { Epigraphic } \\
\text { reference to the } \\
\text { office of hiereus of } \\
\text { Drusus hypatos }\end{array}$ & $\begin{array}{c}\text { Type of } \\
\text { inscription }\end{array}$ & $\begin{array}{c}\text { Further } \\
\text { observations, other } \\
\text { epigraphic } \\
\text { references and } \\
\text { bibliography }\end{array}$ \\
\hline $\begin{array}{l}\text { AD 61/2 } \\
\text { (cf. Schmalz, } \\
\text { Athens 202- } \\
\text { 203, no. 261) }\end{array}$ & $\begin{array}{l}\text { C. Carrinas } \\
\text { [Secundus] } \\
\text { (neoteros) }\end{array}$ & $I G$ II $^{2} 4188$ & $\begin{array}{l}\text { Honorary } \\
\text { inscription }\end{array}$ & $\begin{array}{l}\text { Likely to be } \\
\text { identified with the } \\
\text { Neronian 'agent' } \\
\text { who was sent by } \\
\text { the emperor to } \\
\text { Greece in pursuit of } \\
\text { works of art (Tac. } \\
\text { Ann. 15.45; Dio } \\
\text { Chrys. Or. 31.148; } \\
\text { Plin. HN 36.34; cf. } \\
\text { PIR C } 450 \text { ); he is } \\
\text { probably the son of } \\
\text { the Sekoundos who } \\
\text { was eponymous } \\
\text { archon in Athens } \\
\text { around AD 40 (see } \\
\text { supra). See also SEG } \\
29 \text { (1979) 153. Cf. } \\
\text { Byrne, Roman } \\
\text { Citizens 100, no. 6; } \\
\text { Schmalz, Athens 63- } \\
64, \text { no. 78; 202-203, } \\
\text { no. 261. }\end{array}$ \\
\hline (?) Ca. AD 80 & - - - - - - - & $I G$ II $^{2} 1995$ & $\begin{array}{l}\text { Ephebic } \\
\text { catalogue } \\
\text { (formula of } \\
\text { eponymity) }\end{array}$ & $\begin{array}{l}\text { The title of hiereus } \\
\text { is integrated. }\end{array}$ \\
\hline AD 80-90 & $\begin{array}{l}\text { L. Flavius } \\
\text { Flamma }\end{array}$ & $I G$ II $^{2} 3543$ & $\begin{array}{l}\text { Honorary } \\
\text { inscription }\end{array}$ & $\begin{array}{l}\text { See also IG } \text { II }^{2} 3114 \\
\text { and 3544; SEG } 19 \\
(1963) 206 .\end{array}$ \\
\hline Ca. AD 90 & $\begin{array}{l}\text { T. Flavius } \\
\text { Konon }\end{array}$ & SEG 31 (1981) 122 & $\begin{array}{l}\text { Decree } \\
\text { (formula of } \\
\text { eponymity) }\end{array}$ & \\
\hline
\end{tabular}


AtHenian Hiereus of DRUSUs Hypatos

\begin{tabular}{|c|c|c|c|c|}
\hline Chronology & Name of priest & $\begin{array}{l}\text { Epigraphic } \\
\text { reference to the } \\
\text { office of hiereus of } \\
\text { Drusus hypatos }\end{array}$ & $\begin{array}{c}\text { Type of } \\
\text { inscription }\end{array}$ & $\begin{array}{c}\text { Further } \\
\text { observations, other } \\
\text { epigraphic } \\
\text { references and } \\
\text { bibliography }\end{array}$ \\
\hline AD 91/2 & $\begin{array}{l}\text { Q. Trebellius } \\
\text { Rufus } \\
\text { (native of } \\
\text { Toulouse) }\end{array}$ & $\begin{array}{l}\text { 1) IG } \mathrm{II}^{2} 4193,11 . \\
\text { 12-13, } 33 \\
\text { 2) J.H. Oliver, } \\
\text { "Greek } \\
\text { Inscriptions", } \\
\text { Hesperia } 10 \text { (1941) } \\
74,1.5\end{array}$ & $\begin{array}{l}\text { Honorary } \\
\text { inscriptions }\end{array}$ & $\begin{array}{l}\text { See also IG } \text { II }^{2} 1997, \\
2893 \text { and } 4481 .\end{array}$ \\
\hline $\mathrm{AD} 100 / 1$ & $\begin{array}{l}\text { L. Vibullius } \\
\text { Hipparchus }\end{array}$ & $I G$ II $^{2} 3572$ & $\begin{array}{l}\text { Honorary } \\
\text { inscription }\end{array}$ & $\begin{array}{l}\text { See also IG II } 2030 \\
\text { and 3980; I.Délos } \\
\text { 2535, 1. 27; Iv0 } 627 \\
\text { (with Byrne, Roman } \\
\text { Citizens 478, no. 2, } \\
\text { ref. iii). }\end{array}$ \\
\hline $\mathrm{AD} 104 / 5$ & $\begin{array}{l}\text { Ti. Flavius } \\
\text { Alcibiades }\end{array}$ & $I_{G} \mathrm{II}^{2} 3589,11.5-6$ & $\begin{array}{l}\text { Honorary } \\
\text { inscription }\end{array}$ & $\begin{array}{l}\text { See also IG II }{ }^{2} 3590 \\
\text { and } 3592,11.3-7 ; \\
\text { I.Délos } 2536 .\end{array}$ \\
\hline
\end{tabular}

Francesco Camia

National Hellenic Research Foundation Institute of Historical Research Department of Greek and Roman Antiquity (KERA) fcamia@eie.gr 


\section{Summary}

A cult for Drusus the Elder was instituted in Athens following Drusus' death in 9 BC. In inscriptions the priest of this cult is referred to as "hiereus of Drusus hypatos". This priestly office was associated with the charge of eponymous archon, as shown by the fact that all preserved Athenian laterculi archontum dated after $9 / 8$ BC mention the priesthood of the consul Drusus next to the office of archon. Based on the analysis of the epigraphic references (around twenty) to the priesthood of the consul Drusus one can argue that the latter disappeared sometime between ca. AD 105 and 140. At the end of the 19th century Dittenberger had stated that the proliferation of honours for the emperor Hadrian following his first official visit to the city (AD 124/5) would have finally provoked the end of Drusus' priesthood. Indeed, the cult of Drusus must not have survived beyond Hadrian's reign, yet I hypothetically suggest that Hadrian's visit as a privatus in $111 / 2 \mathrm{AD}$, when the future emperor was offered the eponymous archonship without apparently holding the office of priest of Drusus, may have been the first act of its disappearance. I suggest that for reasons of convenience in that year the office of hiereus of Drusus hypatos may have not been held, and this event could have brought about the end of this priesthood, either immediately or gradually over the following years. 